Socialist Studies: the Journal of the Society for Socialist Studies 6(1) Spring 2010:45-64

Copyright (C) 2010 The Author(s)

ARTICLE

\title{
The Limitations of Global Social Movement Unionism as an Emancipatory Labour Strategy in Majority World Countries
}

\author{
ZIA RAHMAN and TOM LANGFORD \\ Department of Sociology, University of Dhaka. Dhaka, Bangladesh \\ Department of Sociology, University of Calgary. Calgary Alberta, Canada.
}

\begin{abstract}
This study assesses the applicability of Peter Waterman's model of global social movement unionism as an emancipatory labour strategy in Bangladesh, an important site for the manufacture of ready-made garments in the neo-liberal era. Our main conclusions are that Waterman's North Atlanticist model fails to comprehend the present-day necessities and struggles of the Bangladesh working class; ignores the impacts of colonialism, militarism and imperialism on Bangladesh's socio-economic development and labour movement; and privileges democratic dialogue as a means of action when militant collective mobilization has been shown to be the only effective way to get action on workers' issues in countries like Bangladesh. Our recommendation is for Waterman and others to abandon the quest for a universal model of progressive labour unionism and instead come up with a variety of models that apply to different typical patterns of socio-economic and labour movement development in the globalized world.
\end{abstract}

\begin{abstract}
Tom Langford is a political sociologist employed by the University of Calgary. He is currently researching how the closing of the underground coal mines affected society and politics in the Crowsnest Pass in the 1950s and 1960s. His book, Alberta's Day Care Controversy: From 1908 to 2009--and Beyond, is forthcoming from AU Press in Edmonton. His email is langford@ucalgary.ca. Zia Rahman is an Associate Professor of Sociology, University of Dhaka Bangladesh. Presently he is on study-leave from his job, and is a Ph.D. candidate of Sociology, University of Calgary, Canada. The title of his dissertation is "Labour unions and labour movements in the ready-made garment industries in Bangladesh in the era of globalization", under the supervision of Langford. His areas of interest are Sociology of Development, Urban Sociology and Social Movements. His email is zia_soc71@yahoo.com.
\end{abstract}

Tom Langford est un sociologue politique qui travaille à l'Université de Calgary. Actuellement, il cherche en quoi la fermeture des mines de charbon souterraines a affecté la société et la politique à Crowsnest Pass dans les années 50 et 60. Son livre, Alberta's Day Care Controversy: From 1908 to 2009--and Beyond, va paraître dans les éditions AU Press à Edmonton. Son courriel est langford@ucalgary.ca. Zia Rahman est professeur associé de sociologie à l'Université de Dhaka, Bangladesh. Actuellement, il est en disponibilité et doctorant en sociology, l'Université de Calgary, Canada. Le titre de sa thèse est 'Les syndicats et les mouvements ouvriers dans l'industrie textile au Bangladesh dans un ère de mondialisation', sous la direction de Langford. Ses d'intérêts sont dans les domaines de la sociologie du développement, la sociologie urbaine et les mouvements sociaux. Son courriel est zia_soc71@yahoo.com.

www.socialiststudies.com

ISSN 1918-2821 
Socialist Studies: the Journal of the Society for Socialist Studies 6(1) Spring 2010: 45-64

\author{
Résumé \\ Cette étude évalue l'applicabilité du modèle global de syndicalisme de mouvement \\ social de Peter Waterman en tant que stratégie libératrice au Bangladesh, un site \\ important pour la fabrication de textiles dans l'ère néolibérale. Nos conclusions \\ principales sont que le modèle nord-atlantiste de Waterman échoue à comprendre les \\ besoins et souffrances de la classe ouvrière au Bangladesh aujourd'hui; qu'il ignore \\ l'impact du colonialisme, du militarisme et de l'impérialisme sur le développement \\ socio-économique et sur le mouvement ouvrier ; et qu'il privilégie le dialogue \\ démocratique comme seul moyen d'agir alors que la mobilisation collective militante \\ s'est montrée comme la seule manière efficace d'attirer l'attention sur les questions \\ ouvrières dans les pays comme le Bangladesh. Notre recommandation, pour Waterman \\ et d'autres, est d'abandonner la quête d'un modèle universel du syndicalisme \\ progressiste et au lieu de cela de créer une variété de modèles qui s'appliquent aux \\ différentes réalités du développement socio-économique et du mouvement ouvrier \\ dans un monde globalisé.

\section{Keywords} \\ - Bangladesh ; globalization ; labour ; social movement unionism• Waterman \\ Mots clés \\ - Bangladesh • mondialisation • travail • syndicalisme de mouvement social \\ - Waterman
}

The era of neo-liberal globalization has been characterized by privatization and deregulation as well as the internationalization of many commodity chains that were formerly local, regional or national in scale. These changes in the character of global capitalism have had significant effects on the processes of working class formation and the organization of work. One striking feature of the neo-liberal era has been the uneven geographical growth of the global proletariat: while between 1970 and 2000 the workforce in OECD countries increased by a modest 31 percent (from 307 to 401 million workers), the workforce in developing regions increased by an astounding 91 percent (from 1,120 to 2,138 million workers) (Munck 2002, 7). The general character of the changes in the organization of work is captured by the term 'flexibilization of labour.' Ronaldo Munck argues that 'flexibility, in its multiple but interrelated guises, is probably the defining characteristic of labour in the era of international competitiveness' $(2002,73)$. Flexibilization has created a plethora of workers -- including part-timers and temporary contract employees -- that pose severe organizational challenges to labour unions. This is one of the important reasons that trade union density has fallen in most advanced industrial countries in recent decades (Visser 2006, 45), 
and most analysts would agree with Munck's conclusion that there has been a 'fundamental social weakening of labour during this period' (2002, 128).

In the face of this reality, however, not all students of labour movements are pessimistic. For instance, Beverly Silver contends, 'The late twentieth-century-crisis of labour movements is temporary and will likely be overcome with the consolidation of new working classes "in formation"' $(2003,171)$. Her projection, based upon a path breaking study of the patterns of global labour unrest between the 1870s and 1990s, is that significant labour movements will emerge in the future when production of established products is shifted to new global locations and particularly when new products that command monopoly profits are first brought into mass production (77-79). Other researchers have had their optimism sustained by the successes of particular labour movements, unions or campaigns in the midst of the general reversals of the neo-liberal era. Labour organizations in the majority world that have been promoted as success stories at different times include the Congress of South African Trade Unions (Hirschsohn 1998); the Kilusang Mayo Uno Labour Centre in the Philippines (Lambert 1990); and the Korean Confederation of Trade Unions (Webster et al. 2008, 169-174). In the United States, researchers have hailed successful efforts to organize the unorganized by unions such as the Service Employees International Union (Lopez 2004, 219; Milkman 2006). Furthermore, researchers with radical democratic sympathies have been able to find a few praiseworthy, contemporary examples; these include particular locals of the Canadian Union of Postal Workers (Camfield 2007, 287) and the fledgling Starbucks Workers' Union (Ince 2007, 28). Finally, collaborations between unions in the North and South have been well documented and highlighted (e.g., Lambert and Webster 2001; Frundt 2000).

The study of such successes has spawned attempts to identify a general model of labour unionism that is particularly effective in the era of neo-liberal globalization. The concept of 'social movement unionism' was first applied in the late 1980s and early 1990s to unions in South Africa and the Philippines that allied with and mobilized community groups as a source of power in authoritarian states (Waterman 2004, 217). In the intervening years 'social movement unionism' has become a cornerstone in the burgeoning literature on how unions might best respond to the changed circumstances of neo-liberal globalization (e.g., Moody 1997; Lopez 2004; and Fairbrother and Webster 2008 as one of the articles in a symposium on social movement unionism). 
In most of the contributions to this literature, social movement unionism (SMU) is presented as a shorthand way to reference the conjunction of a praiseworthy set of union characteristics. For example, Kim Moody defines social movement unionism in terms of particular characteristics on five separate variables: (1) union governance: 'deeply democratic'; (2) approach to collective bargaining: 'militant'; (3) relationship to established political parties: 'independent'; (4) strategy for political action: 'reaching out to other sectors of the class, be they other unions, neighbourhood organizations, or other social movements'; and (5) core ethical commitment: 'fights for all the oppressed' (1997, 4-5). Conceptually similar approaches to defining SMU have been taken by Robinson $(2000,110)$, Scipes $(2003,6)$ and Camfield $(2007,287)$, among others, although each approach varies in terms of the particular set of characteristics that are grouped together under the SMU banner.

In contradistinction to virtually everyone else who has published on SMU over the years, Peter Waterman has deliberately embedded his understanding of the concept in a model that draws upon theories of networked capitalism, new social movements and radical communications. This gives his understanding of SMU a systematic theoretical grounding that is missing from that of other contributors. Waterman has identified the distinctiveness of his approach in these terms: 'Most of those who have used the SMU concept have understood it not in terms of an articulation between the two or more bodies of theory, or two complexes of practice [this is Waterman's approach], but in that of an alliance within the class (waged/non-waged), and/or between the class and the popular/community' (2004, 220-21).

Although Peter Waterman apparently coined the name 'social movement unionism' (Waterman 2004, 217) and first presented his ideas under this heading (e.g., 1993), he later started to use slightly different terms in order to emphasize the distinctiveness of his own contribution. Nevertheless, given that Waterman at no time disconnected himself from the broader literature on global social movement unionism $(2001,316)$ and has recently re-identified with the fraternity of SMU scholars (2008), we think his model of unionism is best termed 'global social movement unionism' (or global SMU). Indeed for reasons explained below, we see Waterman's work as the most interesting and challenging model of global SMU and, as a consequence, it is the sole focus of our analysis.

Furthermore, by concentrating on Peter Waterman's scholarship we hope to help correct the unfortunate tendencies in the literature to either ignore his work entirely (e.g., Schiavone 2007) or, more commonly, to identify a 
generic model of SMU that elides Waterman's work with that of other scholars (e.g., von Holdt 2002, 297; Park 2007, 312-315).

This study aims to contribute to the debate on the value of global SMU as an emancipatory labour strategy in majority world countries, with the proviso that only Waterman's version of the concept will be scrutinized. In the next section we discuss the theoretical origins and logic of Peter Waterman's model, list the main elements of his conceptualization and explain why we think his approach is deserving of concentrated attention. This sets the stage for the heart of the paper, a consideration of the applicability of global SMU to Bangladesh. Bangladesh is chosen for consideration both because the country has been an important site for the manufacture of ready made garments in the neo-liberal era and because the Bangladesh labour movement has largely been ignored in the literature on global SMU. The main conclusions from our case study are that Waterman's model fails to comprehend the present-day necessities and struggles of the Bangladesh working class; and ignores the impacts of colonialism, militarism and imperialism on Bangladesh's socio-economic development and labour movement. We conclude by considering whether global SMU should therefore be rejected entirely as an emancipatory labour strategy in majority world countries or whether it should be retained for application on a limited and selective basis.

\section{Waterman's Model of Global SMU}

Peter Waterman's original, systematic presentation of SMU in 1993 'was a synthesis of socialist trade-union theory with that of "new social movement" (NSM) theory' $(2004,220)$. In 1999, his notion of SMU was extended to incorporate radical communications theory from which he 'took ideas on the potential of the information and communications technology for emancipatory movements' $(2004,221)$. In 2004, the concept was further extended to define 'a new kind of labour internationalism' $(2004,249-252)$, later called 'the new global labour solidarity' (2008, 306-308).

It is easy to trace the lineage between socialist trade-union theory and Waterman's model of global SMU with its emphases on class struggles in the workplace, worker control over the labour process and a reduction in working time. Nevertheless Waterman's largest theoretical debt is to theorizing on new social movements. 'From NSM theory,' stated Waterman in 2004, 'I took the significance of radical-democratic identity movements, the equivalence of different radical-democratic struggles, of networking as 
a movement form, of the socio-cultural as an increasingly central arena of emancipatory struggles' (220-21). It is noteworthy that, in his first systematic presentation of SMU $(1993,252)$, Waterman traced his concern with struggles in civil society to Antonio Gramsci through a quote taken from Laclau and Mouffe (1981). More recent expositions, however, do not engage with Gramsci's own thought or with scholars working in the Gramscian tradition. This is further evidence that socialist trade-union theory is a decidedly secondary source for the development of Waterman's conception of global SMU.

Peter Waterman's notion of global SMU has always been laden with a very broad theoretical and political intent. In 1988 he wrote, 'We are talking not simply of a different union model but a different understanding of the role of the working class and its typical organization in the transformation of society' (quoted in Scipes 1992, 83). Therefore Waterman's model is as much oriented to future political possibilities as it is grounded on what labour movements are doing today. Some of Waterman's scholarly peers have objected to the overtly political or 'normative' thrust of his approach. An early critic was von Holdt (2002, 297). More recently, Fairbrother and Webster dismissed Waterman's work as 'a universal normative program ... of what a progressive trade union should look like.' In its stead they advocated for 'an analytical device that allows one to engage in a comparative historically-based analysis' (2008, 310 ). We believe this criticism is short sighted. Peter Waterman's model is an ideal type that uses different theoretical lenses to project a possible future path of development for progressive labour unionism. While comparative-historical research like that favoured by Fairbrother and Webster is adept at testing causal hypotheses, ideal-typical research also has its place - it promotes the systematic reassessment of the overall character of a particular case in light of that case's similarities to and deviations from the ideal type. This sort of case reconstruction simultaneously reveals the heuristic value of the ideal-typical conception. What follows is our distillation of the six key elements of Waterman's notion.

Global social movement unions that practice global labour solidarity:

1. Advance a radical and utopian set of demands concerning work and other social institutions including worker/union control over everything up to and including product selection and investment; the equitable sharing of domestic work; anti-authoritarian, non- 
racist and non-sexist social organization; and 'an increase in free time for cultural self-development and self-realization' $(2004,249)$.

2. Work with a wide variety of other groups in ways that respect those groups' autonomy and thus 'stimulate organizational democracy, pluralism and innovation' $(2004,250)$.

3. Support the production of 'worker and popular culture' apart from dominant institutions $(2004,250)$.

4. Use informational networks to pursue grassroots, international solidarity relationships that are reciprocal rather than hierarchical in character, based on the 'needs, values and capacities of ordinary working people' $(2004,250-251)$ and which aim 'to create a global civil society and global solidarity culture' $(1999,261)$.

5. Overcome 'dependency in international solidarity work by financing internationalist activities from worker or publicly-collected funds' $(2004,251)$.

6. Participate in formal internationalist forums with both labour unions and other progressive organizations $(2004,251)$.

This is a left libertarian ideal type that accords labour unions an important but not a pre-eminent role in the broad, global justice and solidarity movement.

Peter Waterman developed his model of global SMU with reference to the new kind of capitalist society that emerged beginning in the 1970s. At a general level, Waterman argues that global capitalism is fundamentally different and more complex than industrial capitalism: 'the number, significance and scale of social contradictions' are 'dramatically increase[d]' at the same time that labour/capital conflict 'may' become less important (1999, 249). The new social movements (NSMs) 'arising from such contradictions' are termed 'fundamental issue movements' by Waterman 'since peace, ecological sustainability, and human rights for the majority of the world population (women) would seem to be conditions for the existence of any minimally humane society' (250). The NSMs are important for labour movements in two senses: as potential allies and as models of the democratic, horizontal and networked organizational form that is definitive of his notion of global SMU (250).

According to Waterman there is an important political dimension to labour's current crisis. In global capitalism 'the terrain of struggle' has increasingly spread to civil society, creating problems for traditional unions that 'typically prioritize "economic struggle" (against capital), or "political struggle" (against the state).' Furthermore, 'the centrality of the 
nation-state ... has increasingly been challenged, both by international bodies and forces ... and by sub-national communities (regional, ethnic, local)' $(1999,251)$. Waterman contends that conventional unions have found it difficult to operate in this new political environment; hence the need for a new model of unionism.

In a recent paper, Waterman made it clear that his model of global SMU has also been influenced by the trans-national struggles for social justice of recent years.

My feeling is that with a globalised networked capitalism, the history of labour/labour history has to start again. But this time labour has to be understood as one crucial but equal part of what is calling itself the 'global justice and solidarity movement' (GJSM). This movement is beginning to put in question both the capitalist system and the labour movement -- the major subaltern social movement of national-industrial-colonial (and a major one of anti-colonial) capitalism. (2005a, 196)

In our estimation there is much of interest and value in Peter Waterman's model of global SMU. Firstly, rather than blithely forecast that better days are around the corner or concentrate on small victories in the overall pattern of reversal, Waterman theorizes the contemporary crisis for labour movements and in so doing provides insights into how the crisis might be surmounted. Regardless of whether one agrees with the particulars of Waterman's thinking, his theory-driven approach is commendable. Secondly, although at one level Waterman's model is eclectic in that it combines ideas from three distinct theoretical sources, at a more fundamental level it is consistent. This is because it emphasizes the importance of systemic economic processes in understanding the place of labour in the era of globalized networked capitalism $(1999,248-251)$. Thirdly, Waterman highlights what is distinctive about the contemporary era (particularly the importance of the new social movements and new information technologies) while simultaneously recognizing the continuities between global capitalism and the forms of capitalism that preceded it. As a consequence he is neither 'workerist' in orientation nor willing to join with Gorz (1982) and Castells (1996) in bidding farewell to the working class.

We also find Peter Waterman's model of considerable interest because of the way in which it has been developed. While it engages different theoretical sources, it is also the product of the author's practical engagement with labour unions and the global justice and solidarity movement. Furthermore, Waterman has now been popularizing and 
refining his model for almost two decades; this has forced him to clarify the logic of his thinking over time and to create progressively stronger versions of the model. At the same time Waterman has been refreshingly self critical $(2004,239)$, humorous and self deprecating $(2008,303-04)$ in exchanges with critics, thus encouraging constructive dialogue. In choosing Peter Waterman's version of global SMU as the focus of our study, therefore, we are choosing what we think is, for the reasons just enumerated, a unique and engaging model that deserves to be systematically evaluated against additional empirical evidence.

\section{On the Applicability of Global SMU to Bangladesh}

The main strength of Waterman's global SMU model is that it seriously engages the plurality of the contemporary social formation, which is a reality of contemporary worlds in both the South and the North. Furthermore, it has a penchant for a more democratic, open and humanistic approach to Left politics and social transformation. Nonetheless, there are some serious questions about the applicability of the model in the majority world.

The first problem concerns the ambiguous scope of global SMU. Peter Waterman states that his concept 'was not intended to be either populist or thirdworldist'; rather it 'is intended to relate to and be appropriate for our contemporary world' $(1999,247)$. Waterman's problem is that he fails to clarify whether his notion of 'our contemporary world' includes all of the countries of the majority world. Over the last few years, new kinds of labour movements have emerged in the South. Some of these movements represent various kinds of alliances against authoritarian, racial, and military dictatorships (Scipes 1992; Webster and Lipsig-Mumme 2002). Others are community kinds of movements induced mainly by the NGOs and various cooperative/local organizations (Ford 2001; Petras 2002). We find it troubling that Waterman selectively refers to a few majority world working class movements (such as India and South Africa) when discussing his concept but never systematically specifies whether it applies writ large to the variety of labour movements in the South. Our first criticism of global SMU, therefore, is in accord with Ronaldo Munck's view $(2005,233)$ that 'a truly "global" perspective' on labour movements must demonstrate more than a passing acquaintance with the state of different labour movements in the South.

We will develop this criticism by discussing the situation in Bangladesh (one of the many countries absent from Waterman's radar 
screen even though it is a critical site of production in 'our contemporary world'). Even though neo-liberal globalization has integrated North and South very efficiently in terms of production, consumption and distribution, there remain large variations between Southern states and societies on the one hand and Northern states and societies on the other, as well as among the states and societies within the South. The differences exist because of different historical developments of the states, classes and other socio-economic and cultural features. It is our opinion that these historical developments must be taken into consideration while developing a theoretical understanding of labour movements in the contemporary world. Karl von Holdt made a similar point in his study of labour activism in South Africa (one of the countries that spurred the development of the concept of SMU): he questioned 'the transferability of strategies between labour movements located in very different sociopolitical realities.' This led von Holdt to conclude 'that globalization is unlikely to produce the conditions for a globalized SMU.... National reality counts' $(2002,299)$. In their recent critique of Waterman's model, Fairbrother and Webster made a complementary point: 'There is not a universal panacea to the specificity of time and place' $(2008,311)$.

Over time, colonialism, militarism, and imperialism have had significant impacts on each majority world country's labour movement, not to mention the overall socio-economic development of each country. This is why we see that countries that have experienced an extended period of military dictatorship have often developed similar labour movements and labour relations (weakened labour movements, nepotism and corruption, and a malleable force to the political parties). Examples of this generalization are found in studies on Indonesia (Ford 2001), Pakistan (Candland 1999), Argentina (Petras 2002), Chile (Schurman 2001) and the Philippines (Scipes 1992). Sometimes, however, a shared colonial history is trumped by other historical forces that create variation in labour movements. An example of this pattern is India and Pakistan: while both were ruled by the British Empire for more than two hundred years, two different sorts of labour movements developed in the post-independence period (Candland 1999). This is because of their allegiances during the Cold War with, respectively, the Soviet Union and the USA; their differences in political and other institutional development; and the intervention of the military in politics in Pakistan. It is noteworthy that although both countries were forced to adopt the Structural Adjustment Policy (SAP) induced by the International Monetary Fund, the labour movements in India successfully resisted and forced the Indian state to 
RAHMAN \& LANGFORD: The Limitations of Global Social Movement Unionism

abandon the program by not accepting any venture of privatization. Pakistan labour organizations, on the other hand, accepted the SAP (Candland 1999).

A similar situation exists in Bangladesh as in Pakistan. This helps to explain why, when the Bangladesh government in 2002 shut down a fifty year old jute mill, known as the 'Dundee of the east,' and laid off 30,000 labourers (more than 75,000 people lived within the premise of the jute mill), there was no labour resistance (Mahmud 2002). Rather than being militant or organizing in a global SMU fashion, Bangladesh labour movements have tended to be quiescent with the character of a malleable political force, having parochial allegiances to various political parties. Furthermore, Bangladesh labour leaders form a trade union bureaucracy plunged in corruption and nepotism. Another example of the lethargy of the Bangladesh labour movement concerned a horrific recent accident where a newly built four-storied garment factory in Dhaka collapsed because of faulty building construction. Although the collapse caused the death of seventy-three workers and injured one hundred others, there was no labour protest or mobilization (Malek and Rumi 2005).

This brief discussion has highlighted how the labour movements in majority world countries are sometimes alike but sometimes quite different from one another. In studying this spectrum of labour movements one must consider the varied natures of Southern societies, influenced to varying degrees by agrarian, feudal, semi-industrial, and world-factory based industrial economies. Waterman's model of global SMU is incapable of capturing the realities of these labour movements since it is North Atlanticist (Munck's polite term for Eurocentric; 2005, 233) and industrial/post-industrial in orientation. We concur with Munck that the community-based labour movement set in the foreground of global SMU seems to, at best, portray the situation in a few selected third world countries rather than all or even a large proportion of the countries in the South.

One of the most interesting features of the global SMU model is its radical democratic and libertarian values. Nevertheless, these utopian values are the focus of our second criticism: they are misfit for the hundreds of millions of proletarians throughout majority world countries who face a life and death struggle for immediate needs. Effective labour movements in these countries are concerned with the very existence of working people, as can be seen in the experiences of the Zapatistas of Mexico (De Angelis 2000; Edelman 2001) and the Coalition for Urban Poor in Bangladesh (Rahman 2003). This point equally applies to labour 
movements of poor working people in developed countries (e.g., Fuerza Unida of San Antonio in the USA -- Zugman 2003). Such movements concentrate on the struggle for economic redistribution while valorizing a poor working class identity. In theory, Waterman's model is open to this reality since it prioritizes the 'needs, values and capacities of ordinary working people' in the pursuit of global labour solidarity (2004, 250-251). Nonetheless we believe that the faithful pursuit of this priority would lead inevitably to contradictions with the radical democratic and libertarian values at the heart of the model.

Furthermore, even when working class people participate in new social movements or organizations with a global SMU character, their issues and goals are different from that of middle class participants. For instance, working class environmental movements (such as the anti-toxic substance and anti-solid waste disposal movements) are very much related to the questions of survival and immediate needs for poor communities directly affected by neo-liberal globalization.

Our third criticism concerns Peter Waterman's expectation that global social movement unions will be 'autonomous social forces' that collaborate with other autonomous organizations in democratic partnerships $(1999,261)$. This claim would have greater credibility if Waterman had discussed how labour unions in majority world countries achieve the resources necessary to exercise such autonomy. It is our contention that most labour organizations in the least developed countries (LDCs) have very little scope for organizational survival without support from political parties and their intellectuals or the contemporary NGOs.

The state of trade unions in Bangladesh illustrates why the assumption of autonomy is so inapplicable to certain countries. Even before transnational companies began to produce goods in Bangladesh in the early 1980s, there was no strong trade union tradition among private sector workers (Hossain 2005). The situation with private sector unionization has gotten even worse since then. Labour union activities in the ready made garment factories owned by Bangladesh contractors are not prohibited but nevertheless are almost non-existent because of the owners' abusive anti-unionism. At the same time, Bangladesh prohibits by law any activities by labour unions in its Export Processing Zones (Bhattacharya 2001; Khan 2001; Quadir 2007). Meanwhile labour organizations in the public sector do not strongly advocate for workers' welfare and are beset by corruption and nepotism which mainly comes about because of the close links between the trade union bureaucracy and leadership of political parties (Akkas 1999). These negative features of 
public sector unionization originated during the Cold War period (i.e., immediately after the independence from British colonialism) but flourished during the subsequent military regimes (Ahmed 1969; Akkas 1999).

There is one ray of hope on the labour front in Bangladesh, however; it involves the encouragement of working class organizations by NGOs. At first glance such NGO-promoted organizations appear to have some of the characteristics of global SMU as identified by Waterman. However, in no sense should one regard these labour groups as selfconscious and autonomous. The NGO officials provide the necessary training, logistics and resources for mobilizing the working poor and raising their awareness; furthermore this assistance is not widely spread since it goes only to those segments who are directly associated with the respective NGOs. ${ }^{1}$ Two further problems with such sponsored labour organizations should be noted. Firstly, working people engaged in the NGOs are totally dependent on the NGOs' resources and money. Secondly, the activities and various development programs of most of the NGOs depend upon the flow of foreign funding aided by the western core countries, various supranational organizations and other international NGOs (Ford 2001; Quadir 2007). Such financial dependency runs counter to Waterman's own notion of global labour solidarity.

It is also important to note that some Bangladesh NGOs have become large business ventures in their own right. Two of the notable domestic NGOs that have commercial activities (such as cellular telephone service, textile and garment products, printing press, commercial banking and fashion wears) are Grameen Bank and Bangladesh Rural Advancement Committee. Both of these NGOs were highly dependent on Western donor agencies for their initial programs. Although they still receive foreign funding, however, they also use the profits from commercial activities to sustain programs. They therefore appear to diffuse modern capitalist values in Bangladesh (Bertelsmann 2010; Feldma 1997; Quadir 2007; Rashiduzzaman 1998).

The question of resources is indeed crucial for the working poor. It is evident that many NGOs in LDCs such as Bangladesh are funded by

\footnotetext{
${ }^{1}$ Critical studies focused on NGOs are not found in the literature. This information comes from Zia Rahman's interviews of NGO officials in Dhaka in 2007 as well as primary documentary research. The notable NGOs include Nizera Kari, Nari Uddag Kendra, UBINIG, Bangladesh Legal Aid Services (BLAST) and Bangladesh National Women's Lawyers Association (BNWLA).
} 
international agencies. In turn these NGOs have organized, mobilized and developed many working class organizations by providing them with money and resources. They do so as part of their efforts to establish a liberal democratic environment. This is an interesting pattern of working class formation but it definitely does not fit the 'autonomous social force' picture of the global SMU model. It is worth noting that a similar pattern of labour organizing by NGOs existed in Indonesia during the autocratic rule of Suharto. However this campaign was derailed when various international agencies funding the NGOs demanded that their money be used in the area of human rights (Ford 2001).

Furthermore, the development of autonomous global SMU in a country like Bangladesh is severely impeded by both the 'over developed state' (Alavi 1983) and the expansive role of political parties. Kasfir (1998) mentions that the African ruling elites always use state resources and patronage in order to create cleavages in civil society, and this has become a very common scenario in Bangladesh and other LDCs as well. Hence, the development of an independent and autonomous civil society is in doubt, let alone independent and autonomous working class organizations.

The idea of self-sufficient, global social movement unions engaged as 'autonomous social forces' with 'political forces' (Waterman 1999, 261) is a fanciful dream in countries like Bangladesh. Certainly most of the people in the LDCs, including the working class, have become frustrated with the widespread influence of political parties because of their very parochial, bureaucratic, hierarchic, corrupted and authoritarian nature. But at the same time, most segments of the people in the LDCs are materially dependent upon one or the other of the major political parties. Thus rather than withering away, political parties are becoming stronger. In this regard Candland (1999) showed that all ten large labour organizations in India are directly connected to the major political parties that provide all the necessary channels, guidelines, and resources. In Bangladesh, each of the two major political parties likewise has its own labour front (Akkas 1999; Khan 2001).

In fact, the way that the two major political parties strive to control major Bangladesh institutions is a serious concern for citizens, academics and international agencies (Bertelsmann 2010; Quadir 2007; Rashiduzzaman 1998) Among the major institutions targeted by the parties are the judiciary and police (Quadir 2007), government bureaucracy (Jahan 2006) and the military (Rahman 1981). They also strive to control professional organizations such as university teachers associations (Panday and Jamil 2009), journalists, and even cultural 
organizations that represent NSMs. Hence the working class organizations in Bangladesh and many other LDCs have very little capacity to avoid the major political parties' authority.

The NGOs in countries like Bangladesh have the same class basis (the educated middle class) as the NSMs in developed countries. Waterman's model of global SMU also has a distinctly new-middle-class orientation. This is the starting point for our fourth criticism. Educated professionals are making and will continue to make essential contributions to progressive movements. Nevertheless, we question whether a model of unionism congruent with post-industrial middle class values will be able to effectively preserve the rights of the working class in Bangladesh and emancipate them from the brutal slaps of neo-liberalism.

Most of the global proletariat lives in agrarian countries or countries that are at semi-industrial phases. Colonialism, militarism, and imperialism have severely impacted the socio-economic development of these countries and created stagnant labour movements. More recently, the flexibilisation promoted by transnational companies has further weakened many labour movements in the South. Taking this scenario into account, we argue that the giant transnational corporations, the capitalist core countries and their various supranational allies are the main forces in the arrested progress of the labour movements in third world countries. Consequently, any movement to rejuvenate labour should be aimed mainly against these forces. Our point is consistent with a question raised by Ronaldo Munck in relation to Peter Waterman's work: 'How can anyone look around the world today and not foreground imperialism, war, neocolonialism, and resistance' $(2005,233)$ ?

Our fifth criticism concerns the implications of the 'digital divide' for union organizing in the South. Unlike the post-industrial middle class, which has the leisure time, cultural capital and economic and political securities mentioned by Inglehart (1990), the working class movements in the South are primarily movements for survival and existence. Peter Waterman acknowledges this point with the comment: 'I am, of course, perfectly well award of the distance between the bulk of the world proletariat ... and my Palm [Personal Digital Assistant]' (2005a, 201). However he does not modify his theory accordingly. While union leaders may have access to the internet in LDCs, the vast majority of their members neither have access nor the time available to use it even if they did have access. This profound inequality militates against the development of the horizontal, democratic, participatory labour unions that are suggested by the model of global SMU. Furthermore, the digital divide encourages 
leader-to-leader inter-organizational relations rather than the member-tomember contact emphasized in Waterman's notion of global labour solidarity. It would thus seem that at the present time the global SMU model is only fully suited to industrial/post-industrial countries where majorities of workers have a reasonable amount of disposable income and discretionary time.

Our two final criticisms concern means of struggle and ultimate goals. Global SMU involves a great deal of intra-movement and intermovement dialogue and cooperation. Yet in countries like Bangladesh, trade union relations with the authorities need to be intensely adversarial since neither the government nor the employer care for any minimum level of welfare for workers. The whole society still carries out the old traditions of loyalty, authority and rigid hierarchical relationships where a poor worker has very little scope to talk face-to-face with his employer or with the state agencies. This observation lines up with the finding of two recent studies that employers and the state apparatuses never show any interest in workers' conditions until they feel strong pressure from the working class organizations (Petras 2002; Lee 2003). The question we raise, then, is whether labour unions in majority world countries should be committing limited resources to furthering democratic dialogue when militant collective mobilization is what gets results? In an ideal world these strategies would not be in conflict, but the situation in countries like Bangladesh is far from that ideal.

This leads us to one final comment on the ultimate goal of union struggles in majority world countries. It is noteworthy that Peter Waterman (2005a and 2005b) expresses a strong commitment to the global justice and solidarity movement and promotes a utopian future of humanistic 'cultural self-development' that is incompatible with global capitalism. However Waterman does not explicitly identify global SMU as anti-capitalist. Workers in Bangladesh and many other countries face colonialism, militarism, authoritarianism and imperialism. If we see these as different phases of capitalist development (e.g., Munck 2002) then any emancipatory labour movement should stand primarily against capitalist exploitation. Capitalism perhaps does not seem like such a bad thing from the relative comfort of a post-industrial, new middle class subject position. However from the standpoint of hundreds of millions of workers and their families around the globe, it is a cruel, brutal and heartless socio-economic system. Peter Waterman's model of global SMU captures the revolutionary character of capitalism as a mode of production; however it underplays the 
exploitation, misery and restricted human development that are the primary products of globalized capitalist social relations.

\section{Summary and Conclusion}

The previous section discussed the applicability to Bangladesh of Peter Waterman's model of global social movement unionism. We offered seven reasons why Waterman's model is largely inapplicable for understanding the present situation and future possibilities for the labour movement in Bangladesh. Our argument in summary form is:

1. Peter Waterman's global SMU model is North Atlanticist and industrial/post-industrial in orientation and as a consequence fails to comprehend the reality of the labour movement in Bangladesh and kindred countries in the majority world. In developing his model, Waterman failed to take into account the impacts of colonialism, militarism and imperialism on the socio-economic development and labour movement in countries such as Bangladesh.

2. The radical democratic and libertarian values at the heart of the global SMU model are misfit for the proletariat in most of the majority world countries who face a life and death struggle for immediate needs.

3. Labour unions in countries like Bangladesh are not in a position to act as autonomous social forces. Some are dependent upon NGOs and sponsoring international agencies. Others are dependent upon domestic political parties and the state.

4. The global SMU model is based upon the interests and concerns of the educated middle class in the North and the South. An emancipatory labour strategy for the proletariat in the global South, however, must recognize and target the main sources of the institutional stagnation of the countries in the South, namely the giant transnational corporations, the capitalist core countries and their supranational allies.

5. Most of the proletarians in countries such as Bangladesh do not have access to advanced communication technologies. This militates against the development of horizontal, democratic and participatory unions and social movements, as envisioned by the global SMU model. 
6. Global SMU privileges democratic dialogue as a means of action when militant collective mobilization has been shown to be the only effective way to get action on workers' issues in countries like Bangladesh.

7. Global SMU fails to highlight the misery created by capitalist social relations throughout the majority world and is not explicitly anticapitalist even though its utopian goals are incompatible with global capitalism.

We began this article with a sympathetic presentation of Peter Waterman's ideal-typical model of global SMU. However the model comes up decidedly short when assessed as a potential emancipatory labour strategy in contemporary Bangladesh. Should we, as a consequence, reject as fundamentally flawed Waterman's work on global SMU?

Instead of outright rejection, our recommendation is for Waterman and others to abandon the quest for a single, universal model and instead come up with a variety of ideal types that apply to different typical patterns of socio-economic and labour movement development in the globalized world. The current version of global SMU best fits tendencies in the experiences of labour movements in the North. Nevertheless there are large enough economic, political and social differences among Northern countries and labour movements that even here the 'one model fits all' approach is questionable. Furthermore, when it comes to the majority world the generic model needs both careful revisions and specifications that capture the typical patterns of colonial, post-colonial and imperialistic relations in those countries.

Adding historical specifications and taking seriously the current levels of literacy and economic well being of proletarians in different parts of the globe will inevitably downplay the left libertarian core values of Waterman's current vision of global SMU. Nevertheless these values can survive in specified models both in transitional attenuated forms and as ideals which can only be realized when workers have much higher levels of well being and where democratic civil society organizations are very well established. We remain open to Peter Waterman's argument that the modus operandi of the new social movements is the way forward for labour movements in globalized networked capitalism. For many contemporary labour movements, however, this is a long-term path of emancipation rather than something that is a current possibility. New variants of global SMU will need to distinguish between the practical and 
RAHMAN \& LANGFORD: The Limitations of Global Social Movement Unionism

the utopian dimensions of SMU and suggest how the realization of practical objectives will promote utopian goals.

Finally we continue to believe that, given the opportunities and resources, working people can identify their own problems and necessities and are capable of organizing their own movements of resistance and progressive social change. However support is needed in countries such as Bangladesh because of the deep poverty of the working class, the corrupted and malleable character of existing unions and the neoimperialism of NGOs. In keeping with Peter Waterman's model of global labour solidarity, our hope is that working class and independent citizen organizations in the North will rise to this challenge and provide appropriate resources and logistics in coming years. The more that such solidarity work involves grassroots initiatives and participation, the greater is the likelihood that workers from different countries will learn from each other and global SMU values and organizational forms will gain a foothold even in relatively barren ground.

\section{References}

Ahmed, Kamruddin. 1969. Labour Movement in East Pakistan. Dacca [Dhaka]: Progoti Publishers.

Akkas, A. M. 1999. "Politicization of Trade Unions in Bangladesh: Causes and Consequences." Dhaka University Journal of Business Studies 20, no.2: 37-60.

Alavi, Hamza. 1983. "The State in Post-Colonial Societies: Pakistan and Bangladesh." Pp. 38-69 in Politics and State in the Third World, edited by H. Goulbourne. London: Macmillan.

Bertelsmann, Stiftung. 2010. "BTI 2010 Country Report Bangladesh.” http://www.bertelsmann-transformationindex.de/fileadmin/pdf/Gutachten_BTI2010/ASO/Bangladesh.pdf. (Accessed on 18 February 2010.)

Bhattachrya, Debapriya. 2001. "Export Processing Zones in Bangladesh: Economic Impact and Social Issues.” Working Paper No. 80. Geneva: International Labour Office.

Camfield, David. 2007. "Renewal in Canadian Public Sector Unions: Neoliberalism and Union Practice." Relations Industrielles/Industrial Relations 62, no. 2: 282-304.

Candland, Christopher. 1999. "Labour, Industry and the State in India and Pakistan." In Labour Worldwide in the Era of Globalization: Alternative Union Models in the New World Order, R. Munck and P. Waterman (eds.). Houndmills: Palgrave.

Castells, Manuel. 1996. The Information Age: Economy, Society and Culture. Vol. 1: The Rise of the Network Society. Oxford: Blackwell.

De Angelis, Massimo. 2000. "Globalization, New Internationalism and the Zapatistas.” Capital \& Class 70: 9-33. 
Edelman, Marc. 2001. "Social Movements: Changing Paradigms and Forms of Politics." Annual Review of Anthropology 30: 285-317.

Fairbrother, Peter and Edward Webster. 2008. "Social Movement Unionism: Questions and Possibilities." Employee Responsibilities and Rights Journal 20: 309-13.

Ford, Michele. 2001. "Challenging the Criteria of Significance: Lessons From Contemporary Indonesian Labor History." The Australian Journal of Politics and History 47, no.1: 101-14.

Frundt, Henry J. 2000. "Models of Cross-Border Organizing in Maquila Industries." Critical Sociology 26, no. 1/2: 36-55.

Gorz, André. 1982. Farewell to the Working Class: An Essay on Post-Industrial Socialism. London: Pluto Press.

Hirschsohn, Phillip. 1998. "From Grassroots Democracy to National Mobilization: COSATU as a Model of Social Movement Unionism." Economic and Industrial Democracy 19, no. 4: 633-66.

Hossain, Amzad. 2005. The History of Labour Movements in Bangladesh [in Bengali]. Dhaka: Parua.

Ince, Anthony. 2007. “Beyond 'Social Movement Unionism'? Understanding and Assessing New Wave Labour Movement Organising." Unpublished manuscript.

Inglehart, Ronald. 1990. "Values, Ideology and Cognitive Mobilisation in New Social Movements". In Challenging the Political Order: New Social and Political Movements in Western Democracies, R.J. Dalton and M. Kuechler (eds.). New York: Oxford University Press.

Jahan, Ferdous. 2006. "Public Administration in Bangladesh." Centre for Governance Studies Working Paper Series No. 1. Dhaka: Centre for Governance Studies, BRAC University.

Kasfir, Nelson. 1998. "The Conventional Notion of Civil Society: A Critique." Commonwealth \& Comparative Politics 36, no. 2: 1-20.

Khan, Shamsul I. 2001. "Gender Issues and the Ready-Made Garment Industry in Bangladesh: The Trade Union Context." In Globalization and Gender: Changing Patterns of Women's Employment in Bangladesh, R. Sobhan and N. Khundker (eds.). Dhaka: The University Press Limited and Centre for Policy Dialogue.

Laclau, Ernesto and Chantal Mouffe. 1981. "Socialist Strategy: Where Next." Marxism Today XXV, 1 January: 17-22.

Lambert, Rob. 1990. "Kilusang Mayo Uno and the Rise of Social Movement Unionism." Labour and Industry 3, no. 2/3: 258-80.

Lambert, Rob and Eddie Webster. 2001. "Southern Unionism and the New Labour Internationalism." Antipode 33, no. 3: 337-62.

Lee, Yong-Sook. 2003. "Lean Production System, Labor Unions and Greenfield Locations of the Korean New Auto Assembly Plants and Their Suppliers." Economic Geography 79, no. 3: 321-40. 
RAHMAN \& LANGFORD: The Limitations of Global Social Movement Unionism

Lopez, Steven H. 2004. Reorganizing the Rust Belt: An Inside Study of the American Labor Movement. Ewing, NJ: University of California Press.

Mahmud, Arshad. 2002. "Tears as Jute Mill Shuts with 30,000 Job Losses." The Guardian 1 July 2002. [http://www.hartford-hwp.com/archives/52/026.html . (Accessed on 17 February2010).

Malek, Abdul and Masud Rumi. 2005. “Tragic Man-made Disaster: Building Collapse and the Horrific Death of the Workers in the Spectrum Garments in Savar." Blast Bulletin [in Bengali] June 2005: 4-7.

Milkman, Ruth. 2006. L.A. Story: Immigrant Workers and the Future of the U.S. Labor Movement. New York: Russell Sage Foundation.

Moody, Kim. 1997. Workers in a Lean World: Unions in the International Economy. London: Verso.

Munck, Ronaldo. 2002. Globalisation and Labour: the New 'Great Transformation'. London \& New York: Zed Books.

Munck, Ronaldo. 2005. "Some Comments on Labor in the New World Order." Labor History 46, no. 2: 232-34.

Panday, Pradip Kumar and Ishtiaq Jamil. 2009. "Impact of Politicization on the Recruitment of University Teachers in Bangladesh: The Case of the University of Rajshahi." Paper presented at the NAPSIPAG International Conference on "Human Capital and Good Governance: Transition towards Knowledge Based Development and Well Being." Kedah, Malaysia: Universiti Utara Malaysia, 11-13 December.

Park, Mi. 2007. "South Korean Trade Union Movement at the Crossroads: A Critique of 'Social-Movement' Unionism." Critical Sociology 33: 311-44.

Petras, James. 2002. "The Unemployed Workers Movement in Argentina." Monthly Review 53, no.8: 32-46.

Quadir, Fahimul. 2007. "Country Report: Bangladesh. Countries at the Crossroads 2007.” Freedom House. http://www.freedomhouse.org/uploads/ccr/country-71328.pdf. Accessed on 18 February 2010).

Rahman, Zillur. 1981. "Politicization of the Bangladesh Military: A Response to Perceived Shortcomings of Civilian Government." Asian Survey 21, no. 5: 551-564.

Rahman, Md. Ziaur. 2003. "Urban Policy in Bangladesh: The State, Inequality and Housing Crises in Dhaka City." Calgary: M.A. thesis, Department of Sociology, University of Calgary.

Rashiduzzaman, M. 1998. “ASHA: Critique of NGOs: Bangladesh.” The Weekly Holiday 8 November.

Robinson, Ian. 2000. "Neoliberal Restructuring and U.S. Unions: Toward Social Movement Unionism?" Critical Sociology 26, no. 1/2: 109-38.

Schiavone, Michael. 2007. "Moody's Account of Social Movement Unionism: An Analysis." Critical Sociology 33: 279-309. 
Schurman, Rachel A. 2001. "UNCERTAIN GAINS: Labor in Chile's New Export Sectors." Latin American Research Review 36, no. 2: 3-29.

Scipes, Kim. 1992. "Understanding the New Labor Movements in the 'Third World': The Emergence of Social Movement Unionism." Critical Sociology 19, no. 2: 81-101.

-----. 2003. "Social Movement Unionism: Can We Apply the Theoretical Conceptualization to the New Unions in South Africa -- and Beyond?"

[http://www.labournet.de/diskussion/gewerkschaft/smuandsa.html. (Accessed on 11 July 2009).

Silver, Beverly J. 2003. Forces of Labor: Workers' Movements and Globalization since 1870. Cambridge: Cambridge University Press.

Visser, Jelle. 2006. “Union Membership in 24 Countries." Monthly Labour Review 129, no. 1: 38-49.

von Holdt, Karl. 2002. "Social Movement Unionism: the Case of South Africa." Work, Employment and Society 16, no. 2: 283-304.

Waterman, Peter. 1993. "Social-Movement Unionism: A New Union Model for a New World Order?" Review XVI, summer: 245-78.

Waterman, Peter. 1999. "The New Social Unionism: A New Union Model for a New World Order". In Labour Worldwide in the Era of Globalization: Alternative Union Models in the New World Order, R. Munck and P. Waterman (eds.). Houndmills: Palgrave.

Waterman, Peter. 2001. "Trade Union Internationalism in the Age of Seattle." Antipode 33, no. 3: 312-36.

Waterman, Peter. 2004. "Adventures of Emancipatory Labour Strategy As the New Global Movement Challenges International Unionism." Journal of World-System Research $\mathrm{X}$, no. 1: 217-53.

Waterman, Peter. 2005a. "Labour and New Social Movements in a Globalising World System': The Future of the Past." Labor History 46, no. 2: 195-207.

Waterman, Peter. 2005b. "The Real Movement That Abolishes the Present State of Things." Labor History 46, no. 2: 235-43.

Waterman, Peter. 2008. "'Social Movement Unionism' in Question: Contribution to a Symposium." Employee Responsibilities and Rights Journal 20: 303-8.

Webster, Eddie, Rob Lambert and Andries Bezuidenhout. 2008. Grounding Globalization: Labour in the Age of Insecurity. Malden, MA: Blackwell Publishing.

Webster, Edward and Carla Lipsig-Mumme. 2002. "Recasting Labour Studies in the New Millennium." Society in Transition 33, no. 2: 258-65.

Zugman, Kara. 2003. "Political Consciousness and New Social Movement Theory: The Case of Fuerza Unida." Social Justice 1: 153-77. 